\title{
The Implications of Modern Technology (Gadjet) For Students Learning Development in University
}

\author{
Siti Marpuah ${ }^{\mathrm{a}}$, Wan Ainaa Mardhiah Wan Zahari ${ }^{\mathrm{b}}$, Arwansyah Kirin ${ }^{\mathrm{c}}$, Ummi Mahmudah ${ }^{\mathrm{d}}$, and Syarifah \\ Normawati ${ }^{\mathrm{e}}$
}

A

Centre for General Studies and co-curricullar, Universiti Tun Hussein Onn Malaysia

Centre for General Studies and co-curricullar, Universiti Tun Hussein Onn Malaysia

C

Centre for General Studies and co-curricullar, Universiti Tun Hussein Onn Malaysia

D

Faculty of Islamic Education, Institut Agama Islam Riyadhotul Mujahidin, Indonesia

E

Faculty of Islamic Education, Universitas Ibnu Sina, Batam, Indonesia

Article History: Received: 11 January 2021; Accepted: 27 February 2021; Published online: 5 April 2021

\begin{abstract}
The development of modern technology (gadgets) has led to the widespread use of Internet channels for everyday use among students at the University. Student engagement in the use of gadgets is usually online through mobile phones, computers, tablets and laptops. Generally, social media engagement with modern technology is a new phenomenon experienced by University students who are seen to have implications for their learning. The main objective of the study was to identify the positive and negative effects of gadgets on the development of student learning at the University. In addition, the researcher proposes steps to help students overcome the negative effects of excessive use of gadgets. This study was conducted using quantitative method that is by using 'google form' involving only 50 respondents consisting of students Moral Studies Subject of Year one (I) at Universiti Tun Hussein Onn Malaysia. The results show that the positive effects of the gadgets can help students find information on the subject and make it easier to complete their assignments. Also, using gadgets or modern technology can improve their quality of work. While the negative effect of the use of modern technology on learning is that students spend a lot of time playing video games, surfing social media and others that are on the smartphone. To overcome these negative effects, researchers suggest that every student should be good at dividing time to carry out tasks as students by prioritizing work over video games and social media.
\end{abstract}

Keywords: Implications; Modern Technology (gadgets); Learning development

\section{Introduction}

In the current era of globalization, the change and development of modern technological resources is quite widespread. High-tech inventions and various forms of innovation are produced to impact the rapid development of advanced technology that takes the world into the new millennium. The great impact of the development modern technology has changed the landscape of universal human life regardless of age. In fact, the rapid development of technology today also causes scholars to break the distribution of society based on the mastery of technology. In fact, the rapid development of technology today also causes scholars to break the distribution of society based on the mastery of technology. Among the implications are, modern technology can facilitate to search for information, facilitate communication, accept various private and government affairs and also others. Innovations in these various technological resources are produced to enable today's human communication and interaction to be faster and able to transcend the boundaries of time and place (Official Portal of the National Archives of Malaysia, 2015).

\section{Literature Review}

The development of sophisticated modern technology that has taken place in recent years has led to the widespread use of various electronic devices and devices by every generation, especially among the younger generation. Usually, the application of moral and humanitarian values from one generation to the next occurs through the education of parents, adults and teachers in schools. However, according to a study by Rezki (2009) found that modern life has been influenced by modern technology and a cultured society with media where most cultural ideologies and the application of values are passed down from one generation to another through media such as television and the internet. Thus, children and adolescents are also the group that is no exception to feel the effects of the boom of technological development that has had a huge impact on their lives.

In general, there is a lot of research that has been conducted on this topic. According to Naquiah Nahar, Sahrunizam Sangi, Dharsigah A / P Baniear Salvam, Nurhidayu Rosli, and Abdul Hafiz Abdullah "The Negative Impact of Modern Technology in the Life and Development of Children to Adolescence" (2017), they say that 
technology is something we cannot stop or hinder its development. Denying modern technology in the lives of children and adolescents means 'killing' its development in the digital age and globalization.

Ani Omar (2016) from Sultan Idris University of Education said, that to produce students who are highly productive, proficient in communication, have high-level thinking skills as well as proficient in the use of information and communication technology (ICT). The various applications used in the construction of blogs, animation creativity, audio materials and interactive games have facilitated and further strengthened the $\mathrm{T} \& \mathrm{~L}$ methods. This is said to be so because it can attract more students to use the existing technology in the present time, which is the 21 st century.

According to Mohd. Noorhadi Mohd. Yusof and Zurinah Tahir "The Importance of the Use of Social Media Information Technology in IPT Education" (2017), they argue that the use of technology media is very important in the modern era now because it benefits the national education and forms knowledgeable human capital. Thus, in the context of education in public universities, the use of technological media in education is necessary to improve existing methods and approaches in a more systematic and efficient teaching and learning process.

According to Chan Yuen Fook (Ph.D) Gurnam Kaur Sidhu (Ph.D), "The Role of Information Technology Towards Increasing Learning Motivation Among University Students" (2013). They have done a study at Universiti Teknologi MARA on the Role of Information Technology Towards Increasing Learning Motivation Among University Students. In short, Information and Communication Technology is a major skill and also a major theme in the information technology era. It is also one of the important tools to motivate learning. Recent developments in education have highlighted the importance of Information and Communication Technology that should not be neglected in terms of teaching and learning. This study also shows that the use of technology has been able to increase the motivation of students to learn.

In a research conducted by Rowan (2010) found that on average children spend eight hours a day on entertainment technology with $65 \%$ of them having television in their own bedroom, and $50 \%$ of television in residential homes. Coupled with the use of smartphones, surfing the internet and social media has led to the spread of the influence of technology in the life and social environment of a family.

In this fast-paced era of globalization and borderless high technology, the development of children to adolescence is very easily influenced by socializing agents such as the media. The influence of technology on child development is also strengthened by the findings of the study of Zakaria, Ahmad Munawan and Noranizah (2012) that modern technology, especially the media, is very influential on children's education, behavior and personality.

If 20 years ago, the world of children was filled with outdoor play activities, cycling and so on, but children in the 21 st century are exposed to the use of various technological equipment such as television, internet, computers, smartphones and video games. On average, children spend eight hours a day using such technological equipment, causing their development to be influenced by the technological resources available in their lives.

The development of technology has forced children to grow up in an environment that has a dumping of access to information without borders. Today's children rely on technology in almost all activities including their play activities, so that traditional outdoor play activities such as batu seremban, long poles, konda kondi and so on have been taken over by various modern technological equipment. Thus, this phenomenon has indirectly caused the development of children to adolescence has been influenced by its exposure to technological resources found in life and the environment. This study examines the issue of how the technological boom has a negative impact on the lives of children to adolescents which is an important asset to the future of the country.

However, there is no denying that the use of various modern devices such as the internet can provide a fast, easy, and free social environment to anyone including children and adolescents. However, uncontrolled internet applications have invited addiction among its users, some of whom are school students. Studies involving various age groups also found that the generation between the ages of 18-25 years, that is, adolescents are more at risk for internet addiction problems, especially university and college students. Wireless internet service is provided free of charge by various parties and is readily available.

Given that the internet is the most influential source of modern technology today in the form of the world's largest computer network that allows information globally to be accessed, the issue of pornographic websites is also in the eyes of children and teenagers. The multimedia elements presented on pornographic websites can not only be viewed by children and teenagers but it can also be easily downloaded and disseminated quickly via email. His study also stated that there are about 80,000 websites that are closely related to pornography were produced between 1999 and 2020 because most such websites are accessible for free.

In addition, according to Sulaiman Salleh, "Smartphones: The Influence on Adolescents" (2017). He said that adolescents are very vulnerable to social media that can be accessed in various ways especially through smartphones. Filling in social media all the time continues to include a variety of information and content that can 
contribute to the development of adolescent personality, whether in good shape or otherwise. It also found that there is a clear relationship of influence between smartphones and media. The influence of role models, the cultural pollution caused by it as well as the unbalanced flow of information that contradicts the culture of the society of this country, are often found in social media using the medium of smartphones especially.

\section{Research methodology}

This research is a quantitative research with research design methods through questionnaires using Google Form. The research method used is very important because it can ensure that the researcher can carry out this study in more detail and systematically. The resulting Google Form is disseminated through social media applications such as Whatsapp and Telegram to make it easier for UTHM students to answer the Google Form. The question posed to students is about the extent to which the impact of gadgets on the development of education of UTHM students is either positive or negative. This Google Form is limited to 50 respondents only.

Quantitative data obtained using Google Form were analyzed using two types of statistical procedures, namely pie charts and bar graphs. Also, make improvements using line graphs. The data obtained will be presented in the form of percentages and frequency tables. All data is processed using Microsoft Excell software.

\section{Research Findings}

In this chapter, researchers will present research findings related to gadgets that are often used by students, the need for the use of gadgets among university students as well as the positive and negative effects of the use of gadgets among university students and proposes steps to help students overcome the negative effects of excessive use of gadgets.

a. Gadgets often used by students at university.

The following table is a summary of information related to gadgets often used by university students.

Table 4.1 : $\quad$ Gadgets often used by university students.

\begin{tabular}{|l|c|c|l|l|}
\hline \multicolumn{1}{|c|}{ Gadgets } & Smart phone & Laptop & Tablet & Computer/Pc \\
\hline $\begin{array}{l}\text { Number of } \\
\text { respondents }\end{array}$ & 46 & 3 & 1 & 0 \\
\hline Peratusan (\%) & 92 & 6 & 2 & 0 \\
\hline
\end{tabular}

Table 4.1 shows the gadgets that are often used by students at the university. The results of the study found that the majority of respondents, namely 46 respondents with a percentage of $92 \%$ often use their smartphones at university. Next, there are three (3) respondents with a percentage of $6 \%$ often use laptops at the university. In addition, only one (1) respondent with a percentage of $2 \%$ often use their Tablet in university.

b. Reasons for the use of gadgets by students at the university

The findings of the study for the second question are related to the reasons for the use of gadgets among university students. In this question, respondents are asked to choose two (2) answer options that best suit themselves. Based on the results of the study on the above, it was found that a total of 41 respondents representing $82 \%$ stated that they use gadgets to obtain information. In addition, a total of 30 of our respondents representing $60 \%$ stated that they use gadgets to communicate with others.at the university.

Next, there are 20 respondents with a percentage of $40 \%$ stating they use gadgets to surf social media. In addition, our study also found that only five (5) people represent $10 \%$ express themselves using gadgets to watch videos, movies or dramas. Finally, there are only four (4) people representing $8 \%$ stating they use gadgets to organize their daily activities. In conclusion, we found that most of our respondents used gadgets to get information and also connect with others.

c. Identify the positive effects of the use of gadgets on university students.

The findings of the study are related to the positive effects of the use of gadgets on university students. In this section, respondents are asked to choose two (2) answer options that best suit themselves. Based on our study on the above, we found that a total of 45 respondents representing $90 \%$ stated gadgets help them complete the assignments given by the lecturers. In addition, a total of 24 respondents representing $48 \%$ stated that gadgets help in improving the quality of their work.

Next, there are a total of 12 respondents with a percentage of $24 \%$ stated that gadgets can help themselves to get rid of boredom. In addition, our study also found that a total of 18 respondents representing $36 \%$ stated that the use of gadgets can fill their free time. Finally, there is only one (1) person representing $2 \%$ stating gadgets make themselves more manageable. In conclusion, we found that most of our respondents experienced positive effects that involved in their learning such as completing assignments and also improving the quality of their work or assignments. 
According to Osland Cvano (2013) that, "Gadget is an English term meaning a small electronic device with various special functions." While Rayner (2016) states, "The term gadget as an object with unique characteristics, has a high performance unit and is related to size and cost." One thing that differentiates gadgets from other electronic devices is the "novelty" element. That is, from day to day, gadgets always come up with the latest technology that makes human life more practical. In this very modern era, technological developments continue to grow. The development of this technology will follow the development of high science. Technology was created to make it easier for human life to perform daily activities and provide positive values. Even so it was originally created to produce positive benefits, instead allowing use for something negative (T.N. Ain, 2013).

Tamayo and dela Cruz (2014), say that the current generation makes technology gadgets as their loyal companions and playmates especially when connected to the internet network. Basically, the use of technological gadgets actually gives a lot of benefits to students especially related to learning. Many past studies have stated the positive effects of technological gadgets as well as helping students' self-development process. Salmah and Malisah (2015) argue that the use of technological gadgets is an effective medium for education, because it provides opportunities for self-learning and educates students to be more creative and innovative.

In addition, learning through technological gadgets can also increase students 'self-motivation to learn and provide benefits to students' intellectual development. Mioduser, Tur-Kaspa and Leitner (2000) also stated that learning through these technological gadgets can provide opportunities for students with learning difficulties to learn and are considered learning tools (Ebbeck et al., 2016). This is because technological gadgets contain various types of software and applications related to education and is one of the attractions for this group to prefer to learn through more interesting methods.

If the change is positive, the learning process will be easier because it is supported by ease of access to the internet. In addition, the use of technological gadgets is one of the effective ways to help the process of student development in terms of fine motor skills. In addition, according to Howard-Jones (2011), video games can benefit the development of skills as well as fine motor coordination through kinesthetic responses as well as visual focus on the game. In addition, video games can also improve students 'thinking skills as well as students' problem solving skills (Ernest et al., 2014) through the activities provided in the video games.

\section{d. Negative Impact of Gadget Use on Student Learning}

In today's modern era, sophisticated gadgets have been introduced to all human beings. A gadget is an electronic device or device that has its own function. Examples of gadgets are, such as smartphones, laptops, and even tablets. These devices are widely used nowadays. Gadgets have also been widely used by students and college students throughout the university. They often use gadgets to find and get the information they need, surf social media and even as a hobby activity such as drawing. Apart from the positive impact of the use of these gadgets, gadgets can also cause many problems to the wearer.

One of the negative effects of gadget use is causing health problems to its users. Gadgets capable of disrupting human health are from the radiation of the gadget itself. Most gadgets emit light to light and show the front cover of the gadget to its users. Studies have found that light has radiation that can interfere with the physical health of the man if exposed for a long period of time. Gadgets like smartphones also have the convenience of communicating with others. From the use of the line as well, smartphones are also capable of producing radiation that is not good for humans if they are exposed for a long period of time. In addition, the use of unlimited gadgets can make its users sleep less and cause their body to always feel tired. Lack of rest to the body as well as the human body can cause them to feel unhealthy. From the fatigue as well, it is able to make them feel tired to do leisure activities. Lack of leisure can cause a person to be inactive in their daily activities. This is very unhealthy for a student if they experience something like this. Therefore, excessive use of gadgets can cause health problems to its users.

In addition, the negative impact of gadgets is that it can affect the education of its users. This is because gadgets such as smartphones and tablets often provide more space for users to download other applications such as online games such as PUBG and Mobile Legends or social media platforms such as Facebook, Instagram and even TikTok. From these interesting applications, it is able to attract the attention of its users rather than to study or review lessons, especially among university students. The use of gadgets for entertainment in filling free time can cause students to forget about the lessons learned in the classroom. In addition, the current use of gadgets in the lecture hall can also cause students not to focus on the learning that is being presented by the lecturer. This causes the knowledge given by the lecturer not to reach students who are using gadgets in the lecture hall or classroom. Thus, the use of gadgets causes students to be unable to focus on their learning and affects the level of Education themselves.

In turn, gadgets can also cause their users to become addicted to the gadget itself. This is because the gadget has features and facilities that are attractive to its users. For example, an interesting feature in a smartphone gadget is a facility such as Artificial Intelligence (A.I.). This facility is widely available in most smartphones. The use of 
A.I. in smartphones causes its users to interact less with the real world and causes them to interact more with the virtual world. This is because the characteristics of A.I. in this smartphone is very easy to use by just talking or typing what we want and it will answer or do what is directed. From this it can also cause its users to lack concentration in the real world and cause them to be more focused on technology. If this happens to someone for a long period of time, they will be more dependent on gadgets than their own environment. It can also cause a person to lose their thinking and also cause them to be less creative. As such, gadget addiction is extremely dangerous to all its users.

Strictly speaking, the use of gadgets is dangerous to its users if not used within the proper limits. If using a gadget without following the proper limits, it will cause many problems such as health problems, affect education and even the addiction of gadgets to its users. This must be overcome by limiting its use so that users such as university students are not affected by the negative effects of the use of this gadget. The findings of the research also show the negative effects of the use of gadgets on students at the university The results of the study showed that the majority of respondents stated that the use of gadgets causes them to sleep less and also causes them to forget their work or assignments.

The use of modern technological equipment such as playing gadgets, surfing the internet, social media, watching TV and so on also has the potential to disrupt students' sleep time. Students in the adolescent category need at least 8 hours a day. The craze or addiction to surfing the internet and playing gadgets for example will cause people to be too engrossed without caring about their bedtime. Lack of sleep has a psychological impact on adolescents including irritability, impaired social skills and poor memory that can affect their academic achievement. This is because, students face poor focus performance during lecture sessions. All learning cannot be learned perfectly. As a result, the quality of academic quality is declining and has a big impact on the future of students.

The study on the problem of addiction to the use of gadgets is supported by the study of Johari and Raja Shahrina (2012) who found that the level of internet use of adolescents is increasing over time compared to previous studies. The findings of their study recorded an increase from only two students out of 149 samples detected facing internet addiction in 2010 increased to 20 people in 2012. In this case, students neglected the work to be done due to excessive use of gadgets. Thus, students will perform the task when it is time to send. In fact, the quality of the work featured is somewhat deteriorating and makes the assignment not quality.

In conclusion, according to Hassan (1999) argues, communication technology tends to allow for a large-scale transformation in human life. These transformations have led to changes in various patterns of human communication, which are in fact interpersonal relations. Face-to-face face-to-face meetings can be carried out at a very long distance through the image level. This is due to the misuse of gadgets. Gadgets are more often used to plunge into the world of social media. The world of social media is a world that has a variety of positive and negative impacts, depending on how students use it

\section{Suggestions to Overcome Problems related to the negative impact of gadgets on university students}

Modern technology has many benefits and benefits in smoothing our daily lives but excessive use of modern technology such as telephones, laptops and so on will have adverse effects such as affecting health, disrupting learning performance among students and can lead to extreme addiction to electronic gadgets. Therefore, there are several ways or steps that can be taken in overcoming the adverse effects.

\section{i. $\quad$ Multiply Physical Activity}

As we know life as a student really requires us to use electronic gadgets such as telephones to facilitate the learning process. However, we should try to minimize the use by dividing time. For example during the day we always use gadgets in learning in the morning, maybe in the evening we can put the gadget aside first and go out to do physical activities such as jogging in the park or playing football with friends. In addition to being healthy, we can also interact physically with other friends compared to virtual interaction which we always do through whatsapp applications, Instagram, facebook and so on.

\section{ii. Maintaining Bedtime}

The use of gadgets at night among students has also caused health problems such as myopia because too often exposed to light from the phone screen due to playing gadgets in the dark. If this activity is not controlled and continued, it will cause vision problems to gadget users out there Excessive use of gadgets at night can lead to dangerous diseases such as high blood pressure and so on. Therefore, students should take care of sleep, limit the use of gadgets at night, for example set a time such as $11 \mathrm{pm}$ has stopped playing gadgets such as telephone and ready to sleep. Adequate sleep is very important because it can keep our brain functioning optimally. A healthy brain can help us in lessons and make us more focused and easier to understand something in lessons. It can help improve our performance in lessons to be more excellent.

iii. Less Play Games 
One of the main attraction factors of electronic gadgets is to play games. Playing games is not a bad activity but if excessive will cause extreme addiction. Good time sharing should be done so that we are not too addicted in playing games such as PUBG, Mobile Legend, PES and others. With this division of time, free time can be used to review lessons with friends and various other activities can be done that can benefit us.

\section{iv. Day Without Phone}

If you are not willing, can try to limit your time with the phone. For example, limit the time to 5 hours without a phone in a day. You can try doing other activities like cooking, reading or going out with friends and chatting to distract you from the phone. Believe me, you will get used to this tactic if you practice it well.

v. Balance Your Day

Try to maintain a 1: 1 ratio of tech-time to real-time in your day-to-day. If you are just sitting in front of a laptop or sitting in front of a cell phone for hours, you should take 3 hours of free time without technology as well.

\section{Conclusion}

As a summary of the findings obtained from the questionnaires distributed to the respondents, it can be concluded that modern technology such as smartphones, laptops and others are very important for students who are studying at university. However, the use of this morden technology has both positive and negative effects. Among the positive effects of the use of modern technology on the development of Education is, with the availability of technology such as smartphones students can find the information they need by using smartphones quickly, and this will save time to find reading material as before students should go to the library to find reference material. In addition, with the advent of modern technology it will make it easier for university students to connect with distant families. Among the negative effects of the use of modern technology on the development of Education is, students spend a lot of time playing video games, surfing social media and others that are on the smart telephones, if this continues students will neglect their studies and spend more available time to play video games. In addition, among the negative effects that occur are. Students often sleep late because of modern technology such as smartphones, if this is not curbed students will not focus in the classroom as a result of sleeping late because they surf social media more often until late at night. Therefore, as a caring society. We must play an important role so that negative things like this do not happen in the future. Among the things that can be done is, each student should be good at dividing time to carry out tasks as students by prioritizing work over video games and social media. If students can divide the two things it will produce graduates who are smart in their studies and smart in managing time.

\section{References}

1. Ani Omar (2016). Integrasi teknologi dalam pengajaran dan pembelajaran kesusasteraan melayu mempertingkatkan keyakinan dan keberhasilan guru semasa latihan mengajar. http://ejournal.upsi.edu.my/index.php/JPB/article/view/2465/1899.

2. Chan Yuen Fook (Ph. D) Gurnam Kaur Sidhu (Ph. D) (2013). Peranan Teknologi Maklumat Terhadap Peningkatan Motivasi Pembelajaran Di Kalangan Pelajar Universiti. Uitm.

3. Mohd. Noorhadi Mohd. Yusof dan Zurinah Tahir (2017). Kepentingan Penggunaan Media Sosial Teknologi Maklumat Dalam Pendidikan Ipta. http://ejournal.ukm.my/ebangi/article/view/22483

4. Naquiah Nahar, Sahrunizam Sangi, Dharsigah A/P Baniear Salvam, Nurhidayu Rosli, dan Abdul Hafiz Abdullah (2017). Impak Negatif Teknologi Moden Dalam Kehidupan Dan Perkembangan Kanak-Kanak Hingga Usia Remaja”. http://eprints.utm.my/id/eprint/84837/1/NaquiahNahar2018_ImpakNegatifTeknologiModenDalamK ehidupan.pdf.

5. Normah Mustaffa, Wan Amizah Wan Mahmud, Fauziah Ahmad, Maizatul Haizan Mahbob \& Helmi Abd. Rahim. (2013). Kebergantungan internet dan aktiviti online remaja di Lembah Kelang.Jurnal Komunikasi, Malaysian Journal of Communication, 1(29), 199-218.

6. Sulaiman Salleh (2017). Telefon Pintar: Pengaruh Terhadap Remaja. http://rmc.kuis.edu.my/irmic/wp-content/uploads/2017/05/Telefon-pintar-Pengaruh-TerhadapRemaja-165-172.pdf 